\title{
PROTECTION OF WIFE'S RIGHT TO MAINTENANCE IN ISLAMIC LAW AND ITS IMPLEMENTATION IN THE MALAYSIAN ISLAMIC FAMILY LAW
}

\author{
Mansur Isa Yelwa*
}

\begin{abstract}
Islamic law guarantees the protection of married women's right to maintenance upon their husbands. The significant role of maintenance in the continuity of the marriage union in Islamic law cannot be overemphasised. The Malaysian statutory law in this context is indeed a model. The Constitution's mandatory prescription for the application of Islamic family law on Muslims is an awesome feature. The Islamic Family Law Act is a replica of the classical texts for easy application. This paper presents the legal framework on maintenance law in Muslim marriages and the legal implication of its violation. Emphasis is laid on the classical texts of Shari'ah from the Qur'an, Sunnah and juristic opinions. Statutory and judicial authorities from the Malaysian legal system are referred to, where applicable. It is observed that the preponderant view among the four Sunni Schools is that of the majority, and interestingly, is the applicable ruling in the Malaysian family law.
\end{abstract}

PhD student, Ahmad Ibrahim Kulliyyah of Laws, International Islamic University Malaysia. E-mail: abuabdirraheem@gmail.com. 
Keywords: women, right, maintenance, Islamic law, Malaysia.

\title{
PERLINDUNGAN TERHADAP HAK ISTERI KE ATAS NAFKAH DI BAWAH UNDANG-UNDANG ISLAM DAN PELAKSANAANNYA DI BAWAH UNDANG-UNDANG KELUARGA ISLAM DI MALAYSIA
}

\begin{abstract}
ABSTRAK
Undang-undang Islam menjamin perlindungan kepada hak wanita-wanita yang telah berkahwin terhadap nafkah oleh suami-suami mereka. Kepentingan peranan nafkah di dalam kesinambungan sesuatu ikatan perkahwinan di bawah undang-undang Islam tidak boleh terlalu ditekankan. Di dalam konteks ini, statut perundangan di Malaysia boleh dijadikan model. Penetapan mandatori Perlembagaan berkenaan dengan pemakaian undang-undang keluarga Islam kepada orang-orang Islam adalah merupakan satu ciri yang sangat menarik. Akta Undang-Undang Keluarga Islam merupakan satu replika bagi teksteks klasik untuk pemakaian yang lebih mudah. Kertas kerja ini membentangkan rangka perundangan bagi undang-undang nafkah di dalam sesuatu perkahwinan orang Islam dan akibat perundangan jika ianya tidak dipatuhi. Penekanan diberikan kepada teks-teks klasik Shari'ah berdasarkan al-Quran, Sunnah dah pendapatpendapat juristik. Rujukan dibuat kepada statut dan penghakiman daripada sistem perundangan Malaysia. Adalah diamati bahawa pendapat yang lebih berpengaruh daripada keempat-empat Mazhab ialah pendapat majoriti, dan menariknya, merupakan peraturan yang terpakai di dalam undang-undang keluarga di Malaysia.
\end{abstract}


Kata kunci: wanita, hak, nafkah, undang-undang Islam, Malaysia.

\section{INTRODUCTION}

Maintenance of wives is a fundamental right conferred to them by Shari'ah. As sole responsibility of the husband, its sufficiency guarantees the wife's obligation to obey and remain within the bound of the conjugal sphere. In the same vein, according to the jumhur, the wife's entitlement to demand for separation in the event of the husband's non-compliance is guaranteed as well. The philosophy of Islamic family law in this context is the protection of the interests and rights of both husband and wife with the objective of building an ideal Islamic society which begins from home. The objective of marriage in Islam is establishing a union whose aim is creating an enduring amity and tranquillity between the spouses. In the Qur'an, Almighty Allah says:
"And among His Signs is this, that He created for you wives from among yourselves, that you may find repose in them, and He has put between you affection and mercy. Verily, in that are indeed signs for a people who reflect." 1

By this verse, Islamic law views divorce as something negative. In other words, divorce is considered an abominable act of the devil to dismantle the ever-arrayed social system of marriage unions in Islam. Imam Muslim narrates:

“Jabir reported that Allah’s Messenger (may peace be upon him) said: Iblis places his throne upon water; he then sends detachments (for creating dissension); the nearer to him in rank are those who are most notorious in creating dissension. One of them comes and says: I did so and so. And he says: You have done nothing. Then one amongst them comes and says: I did not spare so and so until I sowed the seed of discord between a 
husband and a wife. The Satan goes near him and says:

You have done well. A'mash said: He then embraces him."2

In another tradition, it is showed that marriage dissolution is in some cases necessary, Allah generally dislikes its occurrence. Narrated Abdullah ibn Umar:

"The Prophet (peace be upon him) said: Of all the lawful acts the most detestable to Allah is divorce."

Sheikh Bajuri commented on the meaning of the above hadith, stating that although marriage dissolution is detested by Allah, it is permissible. ${ }^{4}$ However, the evils of some men towards their wives necessitate the intervention of Islamic law, which primary role in cases like this is redressing the situation for the benefit of the aggrieved party. Cases involving the infringement of the right of maintenance of married women upon their husbands are not rare in both past and present, thus, growing to be a social menace and consequently, a contemporary phenomenon in the Islamic family law. In most cases, the situation warrants grant of divorce as a remedy for the affected wife.

This paper analyses the legal framework of the position of Islamic family law with respect to a wife's right to maintenance in marriage and the Malaysian Islamic family law position in relation to marriages where such right is deprived. Their provisions are similar, all states in Malaysia have their various enactments on Islamic family law. In this context, the Islamic Family Law (Federal Territories) Act (IFLA) would be referred to as a model reference.

2 Muslim Ibn al-Hajjaj al-Naisaburi, Sahih Muslim, (Beirut: Dar al-Jil, n. d.), Vol. 8 p. 138. Hadith No. 7284.

3 Abu Dawud, Sulayman Ibn al-Ash'ath al-Sajastani, Sunan Abu Dawud, (Beirut: Dar al-Kitab al-'Arabi, n. d.), Vol. 2, p. 220. Hadith, n. 2180. Though the Hadith was graded as weak by Sheikh Nasir al-Din alAlbani in Da'if Sunan Abi Dawud, (Kuwait: Gharas Foundation, 1423), Vol. 2, p. 228.

$4 \quad$ Ahmad bin Naqib al-Misri, 'Umdah al-Salik, (Eng. Trans. By Nuh Ha Mim Keller), p. 556. Retrieved From: <www.islamicbulletin.com> Accessed, Oct. 14, 2011. 


\section{MAINTENANCE IN ISLAMIC LAW}

Maintenance is a fundamental entitlement of the wife in marriage. It is not permissible for a man to marry until he is financially able to bear the maintenance expenses. The Prophet, peace be upon him, commanded those who cannot afford it to persevere and fast. This is based on the following authorities.

"And let those who find not the financial means for marriage keep themselves chaste, until Allah enriches them of His Bounty."5

Husbands are duty bound to bear the maintenance expenditure of their wives throughout their marital lives. Allah has made men responsible for women in the following verses of the Qur'an:

"Men are the protectors and maintainers of women, because Allah has made one of them to excel the other, and because they spend (to support them) from their means." 6

"And the father of the child shall bear the cost of the mother's food and clothing on a reasonable basis."7

"Let the rich man spend according to his means, and the man whose resources are restricted, let him spend according to what Allah has given him. Allah puts no burden on any person beyond what He has given him. Allah will grant after hardship, ease.”

Lodge them where you dwell according to your means, and do not treat them in such a harmful way that they be obliged to leave.”9

[Nur: 32] (trans. Muhammad Muhsin Khan).

[Nisa': 34] (trans. Muhammad Muhsin Khan).

[Baqarah: 233] (trans. Muhammad Muhsin Khan).

[Talaq: 7] (trans. Muhammad Muhsin Khan).

[Talaq: 6] (trans. Muhammad Muhsin Khan). 


\begin{abstract}
'Abdullah Ibn Mas'ud said: "We were with the Prophet while we were young and had no wealth whatever. So Allah's Apostle said, “O young people! Whoever among you can marry, should marry, because it helps him lower his gaze and guard his modesty, and whoever is not able to marry, should fast, as fasting diminishes his sexual power." 10
\end{abstract}

'Abdullah Ibn 'Amr narrated that he heard the messenger of Allah peace be on him saying:

"Sufficient it is as a sin for a man to leave his family starved." 11

In another Hadith he said:

\begin{abstract}
"Fear Allah regarding your women, for you have taken them by Allah's covenant and were allowed to enjoy with them sexually by Allah's Words. You have the right on them that they do not allow anyone you dislike to sit on your mat. If they do that, then discipline them leniently. They have the right to be spent on and to be bought clothes in what is reasonable." 12
\end{abstract}

Bahz bin Hakim said that Mu'awiyah bin Haydah Al-Qushayri related that his grandfather said, "O Messenger of Allah! What is the right the wife of one of us has" The Prophet said: "To feed her when you eat and to clothe her when you clothe yourself..."13

$10 \quad$ 'Abdullah Ibn Mas’ud. Muhammad Bin Isma’il al-Bukhari, Sahih alBukhari, (Cairo: Dar al-Sha’b, 1987), Vol. 7, p. 3. Hadith, n. 5066.

11 Muhammad Ibn 'Abd-Allah al-Hakim al-Naisuburi, al-Mustadrak 'ala al-Shihayn, (Beirut: Dar al-Kutub al-'Ilmiyyah, 1990), Vol. 4, p. 545. He added that it is Sahih in accordance with the conditions of Bukhari and Muslim, though they did not report it.

$12 \quad$ Muslim, Vol. 4, p. 39.

13

Abu Dawud, Vol. 2, p. 122. Graded as Sahih by Albani in Hadith, n. 1907. 
From the above authorities, it can be concluded that maintenance (nafaqah) comprises of the feeding, shelter and clothing. The husband is solely obliged to be responsible for all these even if the wife is rich.

\section{Feeding}

Feeding here includes that the husband is obliged to provide his wife's sustenance daily of the grain that is the staple food of the town in which they live. If the wife demands for something other than the staple food of the town, the husband does not have to provide it for her. He is also obliged to cover the expenses of making it ready for consumption (i.e. grinding, baking, etc., if it be of their customary means for instance) even when she is used to doing it herself, as there would otherwise be need for this expenditure. Also, he must buy the goods that normally accompany a particular variety of food to make it serviceable and agreeable, as much as is customary in the town. The wife also deserves cooking implements and utensils for eating and drinking. It is obligatory for the husband to give his wife the expenditure for her support at the first of each day. If she requires a house maid due to her inability to cook for the family, he is responsible for that and should bear the maintenance of the house maid as well. ${ }^{14}$ The quantity of each of the afore-mentioned commodities is determined by the custom of the town where they live. According to jurists, if husband and wife agree that he gives her monetary compensation in place of the above-mentioned things then she is entitled to and is permissible. ${ }^{15}$

\section{Clothing}

The wife is entitled to the kind of clothing that is customary in town for dressing oneself. What is obligatory is the amount necessary for the

$14 \quad$ Muhammad Ibn Idris al-Shafi 'i, Al-Umm, (Beirut: Dar al-Ma'rifah, 1397 AH), Vol. 5 at 87.

15 See: Abd al-Rahman al-Juzayri, al-Fiqh 'Ala al-Madhahib al-Arba'ah, (Cairo: Dar al-Hadith, 1994), Vol. 4 at 193-194.Vol. 4, at 423-428; al-Misri, at 211. [Engl. Trans. by Nuh Ha Min Keller]. 
woman, which varies according to whether she is tall or short, thin or fat, and with the hot or cold climate of various towns. In the summertime, it is obligatory to provide her with a head covering, shift, under drawers, shoes, and a shawl, because of her need to go out; and the same in the wintertime, plus a cloak to protect her against the cold. If she needs two cloaks because of the extreme cold, it is obligatory to provide them. ${ }^{16} \mathrm{~A}$ Shari'ah complying dress is specially required for her prayers and outings.

\section{Housing}

The wife is entitled to housing of the same quality as that of women of similar standing. The quality of housing depends on the wife herself, while the quality for her clothing and support takes the state of the husband into consideration. The difference is because the expenditures for her support and clothing become her own property and are not merely for her use, while housing is solely for use (meaning that while she can take compensation in price of food or clothing and buy some other kind, she cannot rent a different house). In any case, she is obliged to stay in the lodgings her husband arranges for her. According to some jurists, if she had servants in her father's house, the husband is obliged to provide servants for her. ${ }^{17}$

\section{Other Essentials}

The wife in entitled to what she needs of her health care, articles for personal hygiene, cosmetics for cleanliness and adornment, etc. ${ }^{18}$ These may include oil for her hair, shampoo, and a comb to keep her hair clean, of the kind and amount customary in town, in order to prevent harm to herself. It is also obligatory for him to provide deodorant or the like. The

\footnotetext{
$16 \quad$ Ibid., p. 543.

17 Al-Qirawani, Abdullah Ibn Abi Zayd, Matn al-Risalah, (Beirut: Dar alFikr n. d.), p. 101.

18 Muhammad Ibn Misqir al-Tawil, Ta'addud al-Zawjat fi al-Islam, (alTahrir: Umm al-Qura Publication, n.d.), p. 33.
} 
husband must also bear his wives' medical expenses such as doctor's fees, the purchase of medicine and similar expenses. ${ }^{19}$

In order to emphasise a wife's legal entitlement to these rights, the law allows the woman to take her right from her husband's property without his knowledge and/or consent, in case he deprives her thereof. Bukhari and Muslim narrated thus: A'isha reported: Hind the daughter of 'Utba, wife of Abu Sufyan, came to Allah's Messenger (may peace be upon him) and said: Abu Sufyan is a miserly person. He does not give adequate maintenance for me and my children, but (I am constrained) to take from his wealth (some part of it) without his knowledge. Is there any sin for me? Thereupon Allah's Messenger (may peace be upon him) said: Take from his property what is customary which may suffice you and your children. ${ }^{20}$

In all these wife's entitlements, the Jumhur, including the Shafi' ites, recommended that the amount of expenditure for maintenance should rather be in accordance with the financial status of the husband, not in accordance with the status of the wife herself. ${ }^{21}$

In case of dispute between the husband and wife on whether or not the maintenance is provided by the husband, preference is given to the wife's assertion coupled with her oath. This view is upheld by the Jumhur as supported by the Shafi'ites. ${ }^{22}$

\section{Juristic Opinions on Failure of Maintenance as a Ground for Marriage Dissolution}

\section{The Hanafi School}

Imam Abu Hanifa is of the opinion that the spouses would not be separated on this ground and the husband should not be compelled to leave his

19 Al-Nawawi, Yahya Ibn Sharaf, Rawdah al-Talibin wa 'Umdah alMuftin, (Beirut: al-Maktab al-Islami, 1405 A.H), Vol. 9, pp. 51-52.

$20 \quad$ Bukhari, Vol. 3, p. 103. Hadith, n. 2211; Muslim, Vol. 5, p. 129. Hadith, n. 4567.

$21 \quad$ Al-Nawawi, (Rawdah). Vol. 9, p. 40.

22 Abu Ishaq, Ibrahim Bin 'Ali Bin Yusuf al-Shirazi, al-Muhaddhab fi fiqh al-Imam al-Shafi ‘i, (Damascus: Dar al-Qalam, n. d.), Vol. 2, p. 164. 
wife. ${ }^{23}$ This view was also held by Imam al-Hasan and Imam 'Ata' Ibn Abi Rabah. They based their argument on the Qur'anic verse:

"Let the rich man spend according to his means, and the man whose resources are restricted, let him spend according to what Allah has given him. Allah puts no burden on any person beyond what He has given him. Allah will grant after hardship, ease.”24

\section{The Maliki School}

Imam Malik opines that they should be separated with a single revocable divorce. If within the waiting period he becomes financially capable, then he can take her back. ${ }^{25}$ According to him, the waiting period is reasonably sufficient for the husband to recover financially and also sufficient for the court to ascertain his capability or otherwise.

\section{The Shafi'i and Hambali Schools}

Imam Shafi'i says that where a husband becomes financially incapable of bearing the maintenance expenses of his wife, then they should be separated unconditionally. He added that it is not logically acceptable that he confines her within his wedlock restraining her chances against other men when he cannot bear her maintenance expenses. ${ }^{26}$ Imam Ahmad upheld this view. ${ }^{27}$ They relied on the Qur' anic verse:

"Either you retain her on reasonable terms or release her with kindness." 28

\footnotetext{
23 Muhammad Ibn Abi Sahl al-Sarkhasi, al-Mabsut, (Beirut: Dar al-Fikr, 2000), Vol. 5, p. 324.

$24 \quad$ [Talaq: 6] (trans. Muhammad Muhsin Khan).

25 Malik Ibn Anas al-Madani, al-Mudawwanah al-kubra, (Beirut: Dar alKutub al-'Ilmiyyah, n. d.), Vol. 2, p. 184.

26 Al-Shafi’i, Vol. 5, p. 91.

27 Ibrahim Ibn Muhammad Ibn Tuwayyan, Manar al-Sabil fi Sharh alDalil, (Beirut: al-Maktab al-Islami, 1989), Vol. 2, pp. 301-302.

28 [Baqarah: 229] (trans. Muhammad Muhsin Khan).
} 
They said reasonable terms include maintenance. They added that it is the teaching of the Prophet peace be on him, that separation is the solution in this case, relying on the following authorities:

a. Sa'id Ibn al-Musayyab said - concerning a man who does not have what he would maintain his wife with - he said: "they should be separated." He was then asked: is that Sunnah? He replied: "(yes) it is Sunnah." 29

b. On the authority of Umar - may Allah be pleased with him that he wrote to the generals commanding the troops concerning some men who left their wives alone, that they should pay for their maintenance or divorce them. If they opt for divorce, they should send for the settlement of the cost for what they withheld. ${ }^{30}$

c. Hammad Ibn Zaid had same view, though he added that a period of one year should be given to the husband before the separation is imposed. ${ }^{31}$

\section{The Preferred View}

Looking at the juristic opinions and the values of their respective arguments and justifications we can say that the preponderant views is that of Imams Shafi'i and Imam Ahmad which shows that separation is the best alternative for a marriage where maintenance is wanting. However, the view of Imam Malik is also relevant where there is

29 Ahmad ibn al-Husayn al-Bayhaqi, al-Sunan al-Kubra, (Haidar Abad: Da'irat al-Ma'arif, 1344 AH.), Vol. 7, p. 469. But was graded as weak by Albani. See: Mukhtasar Irwa' al-Ghalil, (Beirut: al-Maktab al-Islami, 1985), p. 429. Hadith, n. 2161.

30 Abdullah Ibn Muhammad Ibn Abi Shaybah, Musannaf Ibn Abi Shaybah, (India: Dar al-Salafiyyah, n. d.), Vol. 5, p. 213. Graded as Sahih in Albani, al-Irwa', Hadith, n. 2162.

$31 \quad$ Ibid. 
anticipation of change on the side of the husband. The views of Imams Shafi'i and Imam Malik are to be preferred due to the following:

1. The cited authorities supporting their view are more reliable from the perspective of jurisprudence.

2. Their justifications are stronger from the legal point of view, considering the protection of Islamic law of the rights of oppressed wives.

3. Considering the legal maxims of maslahah mursalah ${ }^{32}$ and sadd al-dhari'ah. ${ }^{33}$ It is believed that most contemporary cases where women are deprived of their rights of maintenance are deliberate based and not resulting from extreme austerity.

4. The Qur'anic injunctions prohibiting all acts of oppression against women; such as: "But do not hold them in order to hurt them, and whoever does that, then he has wronged himself. And treat not the Verses (Laws) of Allah as a jest.”34

5. Prophetic traditions indicating that a woman has the right to ask for divorce on the ground of lack of maintenance.

Abu Huraira narrates: Allah's Messenger (may peace be upon him) said: The most excellent Sadaqa or the best of Sadaqa (charity) is that after

$32 \quad$ Literally, maslahah means 'benefit' or 'interest.' When it is qualified as maslahah mursalah, however, it refers to unrestricted public interest in the sense of its not having been regulated by the Law giver insofar as no textual authority can be found on its validity or otherwise. See: Kamali, Mohammad Hashim, Principles of Islamic Jurisprudence, (Selangor: Ilmiah Publishers, 2000), at 235.

33 Dhari'ah (pl. dhara'i') is a word synonymous with wasilah, which signifies the means to obtaining a certain end, while sadd literally means 'blocking.' Sadd al-dhara' $i$ ' thus implies blocking the means to an expected end which is likely to materialize if the means towards it is not obstructed. Blocking the means must necessarily be understood to imply blocking the means to evil, not to something good. See: Ibid. at 270 .

$34 \quad$ [Baqarah: 230] (trans. Muhammad Muhsin Khan). 
giving which the (giver) remains rich and the upper hand is better than the lower hand, and begin from the members of your household. He was then asked: who are my household $\mathrm{O}$ messenger of Allah? He said: "your wife is one of your household; she (lawfully) says feed me or else leave (divorce) me.”35

Some jurists recommend an amicable opinion that marries between the above views. They said separation between the spouses may or may not take effect upon the husband's inability to maintain his wife, considering certain points. The marriage is dissolved:

(a) When the husband is well-off but does not or refuses to maintain his wife,

(b) When the wife was deceptively made to believe, at the time of marriage, that the husband was well-off, but later he was found to be destitute.

However, the marriage shall not be dissolved if:

(a) The wife knew at the time of marriage, that the husband was poor,

(b) The husband was well-off at the time of marriage but became poor subsequently due to adverse circumstances; because a rich man may become poor or a poor man may become rich and their wives do not rush to the Qadi for separation. ${ }^{36}$

\section{Legal Exceptions}

The wife relinquishes her right to maintenance and hence, is not legally entitled to seek for divorce in certain situations, namely:

$35 \quad$ Ahmad Ibn Hambal al-Shaybani, al-Musnad, (Cairo: Mu’assah Qurtuba, n.d.), Vol. 2, p. 252. The Hadtith was graded as Sahih by Shu'ayb al-Arna'ut. Hadith, n. 7423.

36 M. A. Wani, Maintenance Rights of Muslim Women: Principles, Precedents \& Trends, (New Delhi: Genuine Publications, n.d.), pp. 3435. 
i. Where the wife fails to fulfill her own part of the marital obligations; such as refusing to submit herself to the husband for sexual relations. "With those of whom you have enjoyed sexual relations, give them their dues.”38

ii. Where the wife voluntarily relinquishes her right of maintenance for the husband as practiced in nikah al-misyar. This is a kind of marriage where conducted on the condition that the husband will only be duty bound to haqq al-mabit, i.e. to share his time with her in relation to her sexual right upon him. ${ }^{39}$ This is based on the Hadith that says: "Muslims are bound by their mutual conditions (in agreements between them), except in case of a condition which prohibits the lawful or legalizes the prohibited."40

iii. Where the wife is incapable of sexual intercourse due to young age or the like. However, this is not agreed upon by all jurists. According to some, where such incapacity is not as a result of her own deed, i.e. natural etc., it may not suffice as a ground to relinquish her right to maintenance. As for the former's view, they based their argument on the fact that the Prophet peace be upon him married A'isha may Allah be pleased with her at the age of six, and hence, did not shoulder the responsibility of her maintenance until after the marriage was consummated. ${ }^{41}$

$37 \quad$ Muhammad al-Mukhtar al-Shanqiti, al-Nikah wa al-Huquq alMurtabitah bihi Min Kitabi 'Umdat al-Fiqh, Vol. 1 at 45. Retrieved From: <www.alshamela.com> (Accessed 12 December, 2011).

$38 \quad$ [Nisa': 24] (trans. Muhammad Muhsin Khan). 13. Retrieved From: <www.alshamela.com> (Accessed 12 December, 2011). Tirmizi. Hadith, n. 1352. 


\section{THE MALAYSIAN LAW POSITION}

In Malaysia, a codified family law applies in all Shari'ah Courts and to all Muslims throughout the country. The Malaysian Muslim family law developed through legislative process, introduced under the various Islamic Family Law Enactments in all the states of Malaysia. ${ }^{42}$ However, each state has own legislation. The list of the various enactments according to the states is as follows: Federal Territories of Kuala Lumpur and Labuan - Islamic Family Law (Federal Territories) Act, 1984;43 Kelantan Islamic Family Law Enactment, 1983; ${ }^{44}$ Malacca - Islamic Family Law Enactment, 1983;5 Kedah - Islamic Family Law Enactment, 1984;46 Negri Sembilan - Islamic Family Law Enactment, 1983; ${ }^{47}$ Selangor Islamic Family Law Enactment, 1984; ${ }^{48}$ Perak - Islamic Family Law Enactment, 1984;49 Penang - Islamic Family Law Enactment, 1985; ${ }^{50}$ Terengganu - Administration of the Islamic Family Law Enactment, 1985; ${ }^{51}$ Pahang - Islamic Family Law Enactment, 1987;52 Sarawak -Enakmen Udang-Udang Keluarga Islam, 1991;53 Perlis - Islamic Family Law Enactment, 1992;54 Sabah - Islamic Family Law Enactment, 1992;55 and, Johor - Islamic Family Law Enactment, 1990.56 Hitherto, all the enactments were subject to subsequent reviews amendments.

These enactments were promulgated by the states in the exercise of the legislative powers conferred on them by Article 74(2) of the Federal

\footnotetext{
42 Majid, M. Kamariah, Family Law in Malaysia, (Kuala Lumpur: Malaysian Law Journal Sdn Bhd, 1999), at 4.

$43 \quad$ Act No. 303 of 1984.

$44 \quad$ Enactment No. 1 of 1983.

$45 \quad$ Enactment No. 8 of 1983.

$46 \quad$ Enactment No 1 of 1984.

$47 \quad$ Enactment No. 8 of 1983.

$48 \quad$ Enactment No. 4 of 1984.

$49 \quad$ Enactment No. 13 of 1984.

$50 \quad$ Enactment No. 2 of 1985.

$51 \quad$ Enactment No. 2 of 1985.

$52 \quad$ Enactment No. 3 of 1987.

$53 \quad$ Ordinance No. 5 of 1991.

$54 \quad$ Enactment No. 4 of 1992.

$55 \quad$ Enactment No. 15 of 1992.

$56 \quad$ Enactment No. 5 of 1990.
} 
Constitution of Malaysia which includes matters relating to the Muslim family law. ${ }^{57}$ The statutory protection of the Muslim wife's right to maintenance in Malaysia is specifically provided in the various states' Islamic family law enactments. All the enactments contain similar provisions for the protection of the wife's right to maintenance. For instance, the Islamic Family Law Act (IFLA) provides thus:

“The Court may, subject to Hukum Syarak, order a man to pay maintenance to his wife or former wife."58

The Act further provided that: subject to Hukum Syarak and confirmation by the Court, a wife shall not be entitled to maintenance when she is nusyuz, or reasonably refuses to obey the lawful wishes or commands of her husband, that is to say, inter alia:

(a) When she withholds her association with her husband;

(b) When she leaves her husband's home against his will; or

(c) When she refuses to move with him to another home or place, without any reason according to Hukum Syara'. ${ }^{5}$

In Section 60, it further provided the power of the Shari' ah court to order maintenance of certain persons. By virtue of section 64, the duration of a maintenance order is usually the death of the person against whom or in favour of whom the order was made, whichever is earlier. Section 65 extends the wife's right to maintenance to the expiration of her iddah period even after divorce. The right of the divorced wife receive a pemberian $^{60}$ from her former husband under an agreement shall cease

$57 \quad$ M. K. Majid, Family Law in Malaysia, (Kuala Lumpur: Malaysian Law Journal Sdn Bhd, 1999), at 5.

$58 \quad$ Islamic Family Law (Federal Territories) Act No. 303 of 1984. Section 59 (1).

$59 \quad$ Islamic Family Law (Federal Territories) Act 1984. Section 59 (2).

60 "Pemberian" means a gift whether in the form of money or things given by a husband to a wife at the time of the marriage. See the Interpretation 
on her remarriage. ${ }^{61}$ Section 66 provides that the court may vary maintenance orders where it is satisfied that that the order was based on misrepresentation or mistake of fact or where there has been any material change in the circumstances. Non paid maintenance may be applied and the court can grant the amount in arrears. ${ }^{62}$

Since the power to dissolve the marriage by a unitary power through talaq is solely vested with the husband in Islamic law, the Malaysian Islamic Family Law has provided two major means by which an aggrieved wife may apply for redress in case of her husband's failure in maintenance. These two means are exercised through the doctrines of fasakh and ta'liq.

\section{Protection of the Wife's Right of Maintenance by Means of the Doctrine of Fasakh}

According to the Act, "fasakh" means the annulment of a marriage by reason of any circumstance permitted by Islamic Law in accordance with Section 52. ${ }^{63}$ By virtue of the application of this doctrine, a woman is entitled to a right similar to that of a man in applying for divorce where he inter alia negligently abandons the wife of deprives her maintenance for specified periods respectively. The Acts provides:

A woman or man, as the case may be, married in accordance with Hukum Syarak, shall be entitled to obtain an order for the dissolution of marriage or fasakh on any one or more of the following grounds, namely-

(a) that the whereabouts of the husband or wife have not been known for a period of more than one year;

of the Act in: Part 1, Sec. 2, Islamic Family Law (Federal Territories) Act 1984 (Act 303).

61 Section 65(2) of the Islamic Family Law (Federal Territories) Act 303 of 1984 was substituted with the provision vide Act A902/94.

$62 \quad$ Ibid. Section 69.

63 See: the Interpretation of the Act in: Part 1, Sec. 2, Islamic Family Law (Federal Territories) Act 1984 (Act 303). 
(b) that the husband has neglected or failed to provide for her maintenance for a period of three months. ${ }^{64}$

This provision, in no small way helps in protecting the wife's right of maintenance as the husband may decide to reconcile with the wife after the notice is issued to him, otherwise judicial divorce takes effect. In Mashitah $v$ Hussain, ${ }^{65}$ the wife applied for fasakh divorce due to nonmaintenance by the husband. She claimed that she was married to him in January 1974 but he left her without maintenance in August same year. He had not given her maintenance since then and had no property within the jurisdiction of the court from which maintenance could be obtained. When the court was satisfied, the Qadhi ruled that the conditions for a fasakh divorce had been fulfilled and granted the wife's application for divorce. ${ }^{66}$ Similarly, in the case of Atikah $v$ Razali, ${ }^{67}$ the wife applied for divorce by fasakh because her husband was taken away by the communists in Cambodia. Since then, she had not heard from him and did not obtain maintenance. The court held that the defendant husband came within the definition of pauper and requested the plaintiff to take a solemn oath to strengthen her case. The court then ruled that she was granted divorce by fasakh. ${ }^{68}$

However, it should be noted that the wife relinquishes her right of maintenance, by virtue of article 59 (2) of the IFLA, when she is in nusyuz, or unreasonably refuses to obey the lawful wishes or commands of her husband. Thus, in Faiza bt Abdul Samad v Abu Bakar bin Abdul Ghaffar ${ }^{69}$ the plaintiff applied for fasakh divorce on the ground that the husband failed to provide her maintenance for a period of 18 months, a period in excess of that stipulated in s. 53(1) (b). The plaintiff's application was granted and the marriage was dissolved.

\footnotetext{
$64 \quad$ Islamic Family Law (Federal Territories) Act 303 of 1984. Section 52(1) (a \& b).

$65 \quad$ [1979] 2 J.A. 153.

66 Kamaruddin, Zaleha, Divorce Laws in Malaysia, (Kuala Lumpur: Malayan Law Journal, 2005) p. 187.

$67 \quad$ [1976] 6 J.H. 108.

68 Ibid.

$69 \quad$ [2010] 1 ShLR at 132.
} 


\section{Protection of the Wife's Right of Maintenance by Means of the Doctrine of Ta'liq}

Another means by which the law guarantees the protection of the wife's right to maintenance is through the application of the doctrine of $t a$ 'liq. In the interpretation part of the statute, the IFLA defines ta'liq as a promise expressed by the husband after solemnization of marriage in accordance with Hukum Sharak or the provisions of the Act itself. ${ }^{70}$ In other words, ta'liq is a conditional or delegated divorce where the wife includes a condition in her marriage contract that allows her to divorce on her own initiative under certain specific circumstances. Under a ta'liq divorce, a woman has the right to divorce her husband if he violates one of the conditions listed in the ta'liq agreement agreed upon at the time of the marriage. These conditions may include desertion, failure to pay maintenance, and harm caused to the wife. Upon a woman's petition, a court will make an inquiry into the validity of the divorce and, if satisfied, the court will confirm and record the divorce. In Malaysia, ta'liq agreement seems to be an ideal means of protecting Muslim women's right in their marriage. Therefore, it is usual for the husband to pronounce the statutory ta'liq agreement in the prescribed form immediately after the marriage is solemnized. ${ }^{71}$

This doctrine serves as a shield for the wife securing her right of maintenance and enforcing the compliance of the husband. On the issuance of $t a$ 'liq certificate and the wife's entitlement to it, the IFLA states that the Registrar shall also, upon payment of the prescribed fees, issue a ta'liq certificate in the prescribed form to each of the parties to the marriage. ${ }^{72}$ The form of $t a^{\prime} l i q$ varies from one state to another, though all serving the same purpose. ${ }^{73}$

\footnotetext{
70 See: the Interpretation of the Act in: Part 1, Sec. 2, Islamic Family Law (Federal Territories) Act 1984 (Act 303).

71 Nora Abdul Hak, Roslina Che Soh, Norliah Ibrahim and Manawee Niringjuerae, "Right of Women to Obtain Divorce under Shari 'ah and Islamic Family Law of Malaysia: With special reference to Ta'liq and Khulu'," Australian Journal of Basic and Applied Sciences, 6 (11): 286-293, 2012.

72 Islamic Family Law (Federal Territories) Act 1984 (Act 303). Section 26 (2).

73 Ahmad Ibrahim, Family Law in Malaysia and Singapore, (Singapore: Malayan Law Journal (PTE) Ltd., 1978), p. 214.
} 
From the case law records, it is observed that ta'liq divorces occur where the wife claims that she has not been paid maintenance. In some instances the husband attends the court; in others he is not present. There are also some cases where the wife applies for ta'liq divorce on the ground of assault by the spouse. In such cases the court will hear both parties and the witnesses and then decide on the evidence. In the case of Salemawegam $v$ Mohd Anuar ${ }^{74}$ the wife applied for ta'liq on the ground of non-maintenance. The husband did not deny that he had not paid maintenance, but alleged that the wife had refused to consummate the marriage. Hence, he claimed that he was not bound to give support. The court asked both parties to take the solemn oath. His wife took the oath and said that there had been sexual intercourse between them. The husband however, had refused to take it as required by the court. It therefore gave judgment in favour of the wife and decreed a ta'liq divorce by one talaq. Similarly, in Aminah $v$ Ahmad, ${ }^{75}$ the wife complained that the husband has deserted her and had not given her maintenance for over three months. The husband admitted that he had not lived with the wife and had not provided her maintenance but said that he had tried to take her back to settle the dispute but this had failed. The wife called two witnesses to support her case. The Kadi gave judgment for the wife and after ascertaining that she was in state of purity decreed that one talaq divorce had been affected. The appeal of the husband to the Appeal Committee was dismissed.

Nonetheless, despite the commendable approach of the Malaysian Islamic family law in guaranteeing the protection of the wife's right to maintenance, the law is not free from criticisms in this respect. It is asserted that the law has certain loopholes in its provisions on the protection of this right whereby some of its objectives are not easily attained by aggrieved women. For instance, Haneef (2008) observed that the fairness of the law in this respect has been questioned on the following grounds:

1. Maintenance awarded to the wife during the 'iddah is according to the financial means of the husband. However, it is often very difficult to produce the required proof for such means.

\begin{tabular}{ll}
\hline 74 & [1983] 5 JH 109. \\
75 & [1971] 3 JH 81.
\end{tabular}


2. When awarding the maintenance, the judges do not take into consideration the living standard in the country at the time of making the order for maintenance.

3. For the husband to escape the burden of maintenance (arrears in an action for $t a^{\prime}(i q)$, he falsely charges the wife with nusyuz because if she is considered to be such, he does not have to pay her anything.

4. The husband also can defy the court award for maintenance when he is self-employed or works in a private company.

5. The husband also defeats it by making it a condition that he will not agree to the divorce (sought by the wife) unless she forgoes her right to ancillary relief, such as maintenance.

6. Ta'liq divorce which is seen as the easiest way for women to get a divorce in Malaysia, the court makes it difficult for requiring the wife to bring two male witnesses to prove that she has not received maintenance or has been physically abused, which are the grounds for such a divorce.

7. Although fasakh divorce can be based on so many grounds, such as cruelty etc, it does not include mental abuse within the purview of such cruelty. It also requires heavy proof on the part of the wife to prove that her husband is abusive, which may be impossible to obtain in the case of emotional abuses. Another aspect is the restrictive definition of inability of the husband to fulfill his marriage obligations. It has many aspects, it could be that he is not a good father or simply that the woman is no longer in love with him, or he is not the partner she needs in her life any more.

8. Inordinate delay of divorce proceedings which may take years due to postponement by lawyers, courts' adjournment and the 
other party's absence from counseling sessions and the court hearing. ${ }^{76}$

\section{CONCLUSION}

Maintenance in the Islamic family system is an obligation on the husband. A look at the theoretical aspect of Islamic family law proves that where the husband is found wanting in providing for the maintenance of his family, a redress is sought. In practice, it is proved that cases involving lack of maintenance amongst Muslim families is on the rise. Divorce is the final solution of redress in marriage. The law allows divorce where necessary as a legal way-out for oppressed women. From this research, the following are salient points of conclusion:

1. Maintenance is an obligation and must be borne as a legal responsibility by the husband.

2. Maintenance is a legal right of the wife and she is the victim where infringement occurs; hence, she alone has the right of pardon or redress.

3. Majority of the Muslim jurists opine that lack of maintenance is a ground for marriage dissolution.

4. In certain situations, the wife may forfeit her right of maintenance and as such, cannot depend on lack of maintenance as a ground for divorce.

5. In Malaysia, the Islamic family law is codified, providing for the right of the wife to obtain divorce on the ground of the husband's failure in maintenance.

$76 \quad$ Haneef, S. S. Shah, "Modern State-Enacted Family Laws: Towards a Purposive Legal Codification,” Sharia Law Reports Articles, Vol. 1, 2008. 
6. Although the form of application varies between the states, all states' laws pertaining to Muslim family law contain provisions for the enforcement of the rules of maintenance, as a protection for the wife's right to ensure husband's compliance with the Shari'ah.

7. A look at the Malaysian model in both the statutory and case law aspects, reflects that the law is generally fair to a certain extent in its provisions for the implementation of Islamic law principles in relation to maintenance in marriage. However, certain facts reveal that there is a need for further review and improvement in the Malaysian Islamic family law. 